\title{
PENGARUH MODEL PEMBELAJARAN CONTEXTUAL TEACHING AND LEARNING BERBANTUAN DISCORD TERHADAP HASIL BELAJAR KOGNITIF SISWA PADA SUB MATERI ALAT INDRA
}

\author{
Hikmah Kurnia Septiani', Romdah Romansyah², Lia Yuslima ${ }^{3}$ \\ ${ }^{1,2,3}$ Program Studi Pendidikan Biologi, Universitas Galuh, Jl. R. E. Martadinata No.150, Ciamis, Indonesia \\ Email : romdah1976@gmail.com
}

\begin{abstract}
The change in the learning process from face-to-face to online due to the COVID-19 pandemic is a challenge for all teachers in Indonesia. The purpose of this study was to determine the effect of the Discord-Assisted Contextual Teaching and Learning Learning Model on Students' Cognitive Learning Outcomes in the Sub-Material of Indra Instruments Class XI SMA Negeri 1 Kawali. This type of research is quantitative research with pre-experimental research methods. The research design in this study was one group pretest-posttest. The instrument used was a test consisting of 20 items pretest and posttest (multiple choice) with Bloom's Taxonomy indicators revised in the cognitive domain, namely C1, C2, C3, C4, and C5. The population in this study were all students of class XI IPA SMA Negeri 1 Kawali for the academic year 2020/2021, totaling 214 people. The sample in this study is class XI IPA 4 totaling 34 people taken by simple random sampling technique. Data analysis used is N-Gain, Normality Test, and Z-Test. Based on the results of

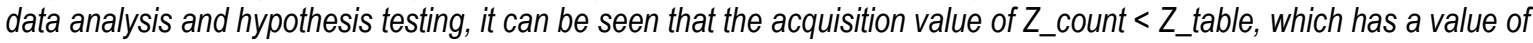
$0.20<1.65$. So it can be concluded that there is no effect of the Discord-Assisted Contextual Teaching and Learning learning model on students' cognitive learning outcomes in the Indra Tool (class XI sub material of SMA Negeri 1 Kawali).
\end{abstract}

Keywords: Discord, Cognitive Learning Outcomes, Contextual Teaching and Learning

\begin{abstract}
ABSTRAK
Perubahan proses pembelajaran dari tatap muka langsung menjadi daring akibat pandemi COVID-19 menjadi tantangan seluruh guru di Indonesia. Tujuan dari penelitian ini adalah untuk mengetahui pengaruh Model Pembelajaran Contextual Teaching and Learning Berbantuan Discord terhadap Hasil Belajar Kognitif Siswa Pada Sub Materi Alat Indra Kelas XI SMA Negeri 1 Kawali. Jenis penelitian ini adalah penelitian kuantitatif dengan metode penelitian pre-eksperimen. Desain penelitian dalam penelitian ini adalah one group pretest-posttet. Instrumen yang digunakan adalah tes yang terdiri dari 20 butir soal pretest dan posttest (multiple choice) dengan indikator Taksonomi Bloom revisi ranah kognitif yaitu C1, C2, C3, C4, dan C5. Populasi dalam penelitian ini adalah seluruh siswa kelas XI IPA SMA Negeri 1 Kawali tahun pelajaran 2020/2021 yang berjumlah 214 orang. Sampel dalam penelitian ini adalah kelas XI IPA 4 berjumlah 34 orang diambil dengan teknik simple random sampling. Analisis data yang digunakan adalah N-Gain, Uji Normalitas, dan Uji-Z. Berdasarkan hasil analisis data dan pengujian hipotesis maka dapat diketahui bahwa perolehan nilai $Z_{\text {hitung }}<Z_{\text {tabel }}$, dimana memiliki nilai $0,20<1,65$. Sehingga dapat disimpulkan bahwa tidak terdapat pengaruh model pembelajaran Contextual Teaching and Learning Berbantuan Discord terhadap hasil belajar kognitif siswa pada sub materi Alat Indra (Kelas XI SMA Negeri 1 Kawali).
\end{abstract}

Kata kunci : Discord, Contextual Teaching and Learning, Hasil Belajar Kognitif

Cara sitasi : Septiani, H.K., Romansyah, R., \& Yulisma, L. (2021). Pengaruh Model Pembelajaran Contextual Teaching And Learning Berbantuan Discord Terhadap Hasil Belajar Kognitif Siswa Pada Sub Materi Alat Indra. J-KIP (Jurnal Keguruan dan IImu Pendidikan), 2(3), 221-228. 


\section{PENDAHULUAN}

Wabah penyakit pandemi berskala besar yang terjadi karena Virus Corona (COVID-19) yang terjadi mulai dari awal tahun 2020 telah mempengaruhi tidak hanya kesehatan manusia, tetapi juga sektor pendidikan. Oleh sebab itu, Kementerian Pendidikan dan Kebudayaan Republik Indonesia mengganti kegiatan pembelajaran tatap muka langsung menjadi kegiatan pembelajaran berbasis daring (online). Upaya pemerintah ini telah diikuti oleh seluruh sekolah di Indonesia mulai dari tingkat dasar (sekolah dasar) sampai tingkat tinggi (perkuliahan) termasuk di SMA Negeri 1 Kawali. Di era modern saat ini, teknologi informasi dan komunikasi berkembang sangat pesat. Belum selesai teknologi dipelajari secara utuh, timbul teknologi baru yang lebih canggih. Hal ini menjadi sebuah perkembangan yang tidak bisa dihindari lagi, baik oleh pendidik maupun siswa. Maka dari itu, hasil belajar siswa diharapkan dapat menumbuhkan keterampilan kompleks agar membantu peserta didik mengikuti perkembangan teknologi yang ada.

Perubahan proses pembelajaran dari tatap muka langsung (offline) menjadi daring (online) menjadi tantangan seluruh guru di Indonesia termasuk di SMAN 1 Kawali untuk mengubah strategi pengajaran dan media pembelajaran. Hasil penelitian dan pengalaman penulis saat melakukan Praktik Pengalaman Lapangan di SMA Negeri 1 Kawali, hasil belajar kognitif siswa cenderung rendah dikarenakan guru tidak memilih dan menggunakan model pembelajaran bervariasi saat pembelajaran daring sehingga mengakibatkan suasana pembelajaran yang monoton terlebih lagi pembelajaran saat ini dilakukan secara daring atau online yang diakibatkan pandemi COVID-19. Hal tersebut dapat terlihat dari masih banyaknya siswa yang mendapatkan nilai kurang dari Kriteria Ketuntasan Minimal (KKM) yaitu 78 sekitar 20\%. Model pembelajaran lebih banyak menggunakan Model Discovery Learning dengan metode penugasan dan ceramah. Aplikasi E-Learning yang digunakan pada saat pembelajaran daring lebih dominan menggunakan Google Classroom.

Dewasa ini upaya yang telah dilakukan untuk membantu siswa dalam memahami konsepkonsep sains adalah dengan mengaitkan materi pelajaran dengan konteks siswa salah satunya yaitu model pembelajaran kontekstual (Contextual Teaching and Learning). Pembelajaran kontekstual (Contextual Teaching and Learning) adalah konsep belajar yang membantu pendidik mengaitkan antara materi yang diajarkannya dengan situasi dunia nyata peserta didik dan mendorong peserta didik membuat hubungan antara pengetahuan yang dimilikinya dengan penerapannya dalam kehidupan mereka sehari-hari (Mulyono, 2018). Pembelajaran kontekstual ini juga dapat meningkatkan pemahan siswa tentang materi pelajaran.

Salah satu media yang dapat menyajikan informasi dan bisa bertukar informasi serta dapat menjadikan pembelajaran menjadi lebih menyenangkan adalah dengan memanfaatkan media $E$ Learning yaitu Discord. Aplikasi discord memiliki fitur untuk berkomunikasi layaknya telepon, video conference, fitur membuat channel atau ruang-ruang khusus yang dapat digunakan untuk menyimpan sumber belajar, ruang agenda kegiatan belajar, ruang diskusi antara kelompok dalam satu kelas dan ruang diskusi dalam satu kelas secara keseluruhan (Rakhmawan, 2020).

Berdasarkan hasil penelitian yang dilakukan oleh Latief (2014) menyimpulkan bahwa terdapat pengaruh hasil belajar yang lebih besar pada kelas eksperimen daripada kelas kontrol dan terdapat pengaruh yang signifikan dari pembelajaran kontekstual terhadap hasil belajar yang ditunjukkan dengan adanya perubahan nilai hasil belajar yang lebih baik dari nilai hasil belajar sebelumnya pada siswa kelas VII SMPN 4 Padalarang. Tujuan penelitian ini adalah untuk mengetahui pengaruh Model Pembelajaran Contextual Teaching and Learning Berbantuan Discord terhadap Hasil Belajar Kognitif Siswa Pada Sub Materi Alat Indra.

\section{METODE PENELITIAN}

Penelitian ini dilaksanakan pada bulan Februari-Juli 2021 di kelas XI IPA 4 SMA Negeri 1 Kawali di Jl. Poronggol Raya No.9 Desa Kawalimukti Kecamatan Kawali Kabupaten Ciamis. 
Penelitian yang dilakukan merupakan penelitian kuantitatif dengan metode penelitian preeksperimen. Desain penelitian yang digunakan adalah one group pretest-posttet. Adapun pola atau desain penelitian one group pretest-posttest menurut Sugiyono (2019) sebagai berikut :

Tabel 1. Desain Eksperimen

\begin{tabular}{ccc}
\hline Pre Test & Treatment & Post Test \\
\hline 01 & $\mathrm{X}$ & 02 \\
\hline
\end{tabular}

Populasi dalam penelitian ini adalah seluruh siswa kelas XI IPA SMA Negeri 1 Kawali tahun pelajaran 2020/2021 sebanyak 212 orang. Dalam penelitian ini sampel diambil dengan teknik simple random sampling yaitu dikatakan simple (sederhana) karena pengambilan anggota sampel dari populasi dilakukan secara acak tanpa memperhatikan strata yang ada dalam populasi itu (Sugiyono, 2019). Berdasarkan teknik ini, terpilih kelas XI IPA 4 yang berjumlah 34 orang. Variabel bebas (X) dalam penelitian ini adalah model pembelajaran Contextual Teaching and Leaning berbantuan Discord. Sedangkan variabel terikat $(Y)$ dalam penelitian ini adalah Hasil Belajar Kognitif Siswa yang terdiri dari aspek mengingat (C1), memahami (C2), mengaplikasikan (C3), menganalisis (C4), dan mengevaluasi (C5).

Instrumen penelitian yang digunakan peneliti dalam penelitian ini adalah butir soal Pretest dan Posttest. Bentuk soal berupa pilihan ganda sebanyak 20 soal. Setelah dilakukan uji coba instrumen dan selanjutnya menganalisis hasil uji instrumen yang meliputi uji validitas butir soal, uji daya pembeda, uji tingkat kesukaran, dan uji reliabilitas instrumen. Prosedur pengumpulan data dibagi menjadi tiga tahap, yaitu : Tahap Persiapan, Tahap Pelaksanaan yang meliputi 1) Memberikan pretest melalui google form, 2) Melakukan proses belajar mengajar dengan menggunakan Model Pembelajaran Contextual Teaching and Learning berbantuan Discord, 3) Memberikan posttest melalui google form, 4) Pengumpulan data hasil belajar kognitif siswa dan Tahap pelaporan, meliputi : 1) Analisis data, 2) Pembahasan dan pengujian hipotesis, 3) Pelaporan penelitian dan membuat kesimpulan akhir

Analisis data hasil penelitian dalam penelitian ini ditempuh dengan langkah-langkah yaitu :

1. Menghitung N-Gain

Untuk memperoleh selisih antara skor pretest dan posttest dilakukan uji N-Gain maka menggunakan rumus gain ternormalisasi. Adapun rumus normal gain adalah sebagai berikut :

$\mathrm{N}-$ Gain $=\frac{\text { Skor } \text { posttest }- \text { skor } \text { pretest }}{\text { skor maks-skor pretest }} \times 100 \%$

Sumber : Lestari \& Yudhanegara (2015)

Dengan kriteria sebagai berikut :

Tabel 2. Kriteria Indeks Gain

\begin{tabular}{lll}
\hline No & Indeks Gain & Kriteria \\
\hline 1 & N-Gain $\geq 0,7$ & Tinggi \\
2 & $0,3 \geq N$-Gain $\leq 0,7$ & Sedang \\
3 & N-Gain $\leq 0,3$ & Rendah \\
\hline \multicolumn{3}{c}{ Sumber : Lestari \& Yudhanegara $(2015)$}
\end{tabular}

2. Uji Normalitas

Data hasil pretest dan posttest dianalisis dengan melakukan uji normalitas, dengan rumus :

$\chi_{\text {hitung }}^{2}=\frac{\sum(O i-E i)^{2}}{E i} \quad$ (Sumber : Sudjana, 2005)

Jika $\chi_{\text {hitung }}^{2} \leq \chi^{2}$ tabel, maka data tersebut berdistribusi normal

Jika $\chi_{\text {hitung }}^{2} \geq \chi_{\text {tabel }}^{2}$, maka data tersebut berdistribusi tidak normal

3. Uji Hipotesis 
berikut :

Data yang didapatkan berdistribusi normal maka menggunakan uji $Z$ dengan rumus sebagai

$\mathrm{Z}=\frac{\frac{x}{n}-p}{\sqrt{\frac{p(1-p)}{n}}}$

Keterangan :

$\mathrm{x}=$ Banyak data yang termasuk kategori hipotesis

$\mathrm{n}=$ Banyak data

$p=$ Proporsi Hipotesis $(0,78)$

Sumber : Sudjana, 2005

Selanjutnya menghitung nilai $Z_{\text {tabel }}$ untuk taraf kepercayaan $\alpha=5 \%$ atau $1 \%$ dengan rumus : Z0,5 $-\alpha$ atau Z0,1 $-\alpha$. Penentuan Hipotesis adalah sebagai berikut : Jika $Z_{\text {hitung }}>Z_{\text {tabel }}$, maka ada pengaruh hipotesis diterima dan jika $Z_{\text {hitung }} \leq Z_{\text {tabel }}$, maka tidak ada pengaruh dan hipotesis tidak diterima

\section{HASIL DAN PEMBAHASAN}

Berdasarkan analisis data meliputi nilai rata-rata, tertinggi, terendah dari setiap pretest, posttest, gain, dan indeks gain dalam jumlah persentase. Data tersebut disajikan pada tabel 3 di bawah ini :

Tabel 3. Data Hasil Penelitian Nilai Kognitif Siswa

\begin{tabular}{cccccc}
\hline Nilai & Pre-test & Posttest & Indeks Gain & $\%$ & Kriteria \\
\hline Rata-rata & 30,1 & 89,9 & 1 & 86,7 & Tinggi \\
Tertinggi & 70 & 100 & 1 & 100 & Tinggi \\
Terendah & 15 & 80 & 0,77 & 77 & Tinggi \\
\hline
\end{tabular}

Berdasarkan tabel hasil penelitian terhadap sampel yaitu kelas XI IPA 4 dengan jumlah peserta didik 34 orang didapat nilai rata-rata untuk pretest yaitu 30,1 dan nilai untuk rata-rata posttest yaitu 89,9. Sedangkan untuk nilai tertinggi pretest 70 dan terendah 15, dan untuk hasil posttest tertinggi 100 dan terendah 80 . Nilai tertinggi indeks gain dalam persentase sebesar 100 dengan nilai terendah indeks gain dalam presentase sebesar 77 dan nilai rata-rata Indeks Gain dalam presentase adalah 86,7 . Berdasarkan hasil perhitungan nilai rata-rata N-Gain yang diperoleh bahwa N-Gain berada pada kategori tinggi. Hasil gambaran subjek yang ada maka ditentukan nilai N-Gain pada kelas eksperimen berdasarkan rata-rata nilai pretest dan posttest, tingkat pengukuran awal siswa yaitu sebesar 30,1 (rendah) sedangkan tingkat pengukuran akhir siswa yaitu sebesar 89,9 (tinggi). Hal ini menunjukkan adanya peningkatan hasil belajar kognitif siswa. Data yang diperoleh diolah secara statistik dengan menggunakan uji $\chi^{2}{ }_{\text {hitung }}$ dan uji $Z$ untuk selanjutnya mengetahui sebaran data uji $\chi_{\text {hitung }}^{2}$ dan uji $Z$ disajikan pada tabel 4 di bawah ini :

Tabel 4. Rekapitulasi Hasil Analisis Data

\begin{tabular}{|c|c|c|}
\hline \multirow{2}{*}{$\frac{\text { No }}{1}$} & Langkah-langkah & Hasil \\
\hline & Normalisasi distribusi & 9,64 \\
\hline & $\begin{array}{l}\text { - } \chi^{2}{ }_{\text {hitung }} \\
\text { - } \chi_{\text {tabel }}^{2} \\
\text { - Kesimpulan }\end{array}$ & $\begin{array}{l}11,3 \\
\text { Karena } \chi_{\text {hitung }}^{2}<\chi_{\text {tabel }}^{2} \text { artinya data } \\
\text { berdistribusi normal }\end{array}$ \\
\hline 2 & Hasil Pengujian Uji Z & 0,20 \\
\hline & $\begin{array}{ll}\text { - } & Z_{\text {hitung }} \\
\text { - } & Z_{\text {tahel }}\end{array}$ & $\begin{array}{l}1,65 \\
\text { Karena } \quad Z_{\text {hitung }}<\end{array}$ \\
\hline
\end{tabular}


tidak diterima

Berdasarkan hasil pengolahan data pada tabel 3 diperoleh bahwa setelah dilakukan uji normalitas bahwa $\chi_{\text {hitung }}^{2}<\chi^{2}$ tabel atau 9,6 $<11,3$ maka data N-Gain terdistribusi normal. Berdasarkan hasil perhitungan uji hipotesis diperoleh $Z_{\text {hitung }}<Z_{\text {tabel }}$ sebesar $0,20<1,65$ maka hipotesis yang diajukan tidak diterima artinya tidak terdapat pengaruh model pembelajaran Contextual Teaching and Learning Berbantuan Discord terhadap Hasil Belajar Kognitif Siswa pada Sub Materi Alat Indra (Kelas XI SMA Negeri 1 Kawali).

Pada saat pembelajaran, sulit mengontrol semua kegiatan belajar mengajar terlebih lagi pembelajaran dilakukan secara daring (online) contohnya dalam kegiatan diskusi kelompok (learning community), pendidik sulit untuk mengetahui siswa mana saja yang mengikuti diskusi bersama kelompoknya. Selain itu, tanpa adanya tatap muka langsung antara pendidik dan peserta didik menyebabkan berkurangnya interaksi antara pendidik dan peserta didik. Minimnya pengawasan dalam melakukan pembelajaran secara daring membuat pengguna e-learning kadang kehilangan fokus. Dengan adanya kemudahan akses, beberapa siswa cenderung menunda-nunda waktu belajar.

Terdapat masalah jaringan saat menggunakan aplikasi Discord dalam pembelajaran sehingga tidak dapat mengoptimalkan dalam kegiatan belajar mengajar untuk mencapai tujuan pembelajaran walaupun fitur yang disajikan aplikasi Discord lengkap. Dalam penelitian ini dikarenakan jaringan yang menjadi kendala sehingga dari jumlah siswa 34 orang terdapat 5 orang siswa yang telat log-in atau masuk dalam aplikasi Discord pada pertemuan ke satu untuk mengikuti pembelajaran dan terdapat 7 orang siswa pada pertemuan kedua yang tidak bisa mengikuti pembelajaran secara daring saat video conference melalui aplikasi Discord. Dengan tugas sebagai jembatan antara materi ajar yang disampaikan pendidik kepada peserta didik menunjukan bahwa tugas media pembelajaran sangatlah penting dalam berlangsungnya kegiatan belajar dan mengajar jarak jauh. Kendala masalah jaringan atau sinyal internet dalam penelitian ini diakibatkan dari area tempat tinggal pendidik yang berbeda-beda dan pemilihan kartu internet untuk menunjang proses pembelajaran. Berdasarkan data, dari 34 orang siswa tidak semua bertempat tinggal di Kawali.

Aplikasi Discord kurang cocok digunakan sebagai solusi pembelajaran jarak jauh. Hal tersebut dikarenakan aplikasi Discord lebih dikenal sebagai aplikasi untuk gamers dibanding sebagai aplikasi yang menunjang pembelajaran jarak jauh. Hal ini relevan dengan hasil penelitian yang dilakukan oleh Fauzi (2020) menyimpulkan bahwa aplikasi discord kurang cocok digunakan sebagai solusi pembelajaran jarak jauh. Hal tersebut dikarenakan aplikasi discord lebih dikenal sebagai aplikasi in-game voice call dibanding sebagai aplikasi yang menunjang perkuliahan jarak jauh. Penggunaan biaya yang hemat adalah salah satu mengapa mahasiswa lebih senang menggunakan aplikasi google meet dan zoom sebagai media perkuliahan jarak jauh.

Pada saat pembelajaran berlangsung dengan menggunakan model Contextual Teaching and Learning berbantuan Discord peserta didik terlihat antusias mengikuti pembelajaran tetapi dalam menerapkan model pembelajaran Contextual Teaching and Learning memerlukan waktu yang panjang sehingga guru sulit untuk menyesuaikan waktu yang telah ditentukan karena terdapat penyederhanaan alokasi waktu saat pembelajaran daring (online). Alokasi waktu pembelajaran yang semula dalam satu pertemuan yaitu 2 jam pelajaran selama 90 menit menjadi 2 jam pelajaran selama 60 menit selama pembelajaran daring (online).

Kelemahan model pembelajaran Contextual Teaching and Learning yaitu 1) Pelaksanaan pembelajaran Contextual Teaching and Learning membutuhkan waktu yang lama bagi peserta didik untuk bisa memahami semua materi 2) Upaya untuk menghubungkan antara materi di kelas dengan realitas di dalam kehidupan sehari-hari peserta didik rentan terjadi kesalahan, sehingga perlu dilakukan berulang-ulang hingga berhasil atau mencapai tujuan target yang diharapkan. 
Pada pembelajaran jarak jauh saat ini sulit melakukan kegiatan inkuiri (inquiry) yaitu merancang kegiatan yang merujuk pada kegiatan menemukan (observasi) tetapi hanya bisa disiasati oleh ilustrasi atau contoh, sumber belajar, media dan lain sebagainya dikarenakan adanya pembatasan kegiatan siswa. Pendidik harus selalu merancang kegiatan yang merujuk pada kegiatan menemukan (Trianto, 2011).

$\mathrm{Hal}$ ini relevan dengan hasil penelitian yang dilakukan oleh Hasnidar \& Elihami (2019) bahwa selama penelitian ada beberapa permasalahan yang menyebabkan tidak adanya pengaruh pembelajaran kontekstual antara lain: 1) Pembelajaran kontekstual tidak berjalan optimal disebabkan karena guru tidak terbiasa menggunakan pembelajaran kontekstual khususnya dalam menerapkan komponen pada model pembelajaran Contextual Teaching and Learning, hal ini berimplikasi terhadap pengelolaan waktu sehingga pelaksanaan komponen pembelajaran kontekstual menjadi tidak maksimal 2) Siswa tidak terbiasa mengikuti proses pembelajaran yang menerapkan model pembelajaran Contextual Teaching and Learning sehingga menyebabkan rendahnya pastisipasi aktif siswa dalam pembelajaran.

Hasil penelitian yang dilakukan oleh Rakhmawan (2020) menyimpulkan bahwa discord dapat digunakan sebagai sarana pembelajaran secara optimal dengan syarat yaitu jaringan internet dari pendidik dan peserta didik stabil dan mencukupi. Namun demikian, dengan jaringan internet yang ada pun discord tetap memiliki kelebihan dibandingkan dengan aplikasi sosial media lain yang umum digunakan oleh masyarakat, yaitu WhatsApp. Hal ini dikarenakan fitur channel yang dimiliki oleh discord memungkinkan discord memiliki kemampuan dalam organisasi informasi yang jauh lebih baik dibandingkan dengan WhatsApp. Aplikasi discord ini tidak cocok jika harus digunakan untuk presentasi layar seperti yang dapat dilakukan oleh beberapa aplikasi video conferences lainnya seperti google meet dan zoom cloud meeting. Hal ini disebabkan karena tingginya pengaruh kestabilan jaringan internet terhadap optimalnya fungsi voice conferences dari discord.

Hasil penelitian yang dilakukan oleh Jatmiko (2017) salah satu kesimpulannya yaitu terdapat perbedaan hasil belajar IPA antara siswa yang menggunakan model pembelajaran Learning Cycle dengan siswa yang menggunakan model pembelajaran Contextual Teaching and Learning. Hal ini berarti bahwa secara keseluruhan penggunaan model pembelajaran Learning Cycle berpengaruh terhadap hasil belajar IPA siswa.

\section{KESIMPULAN}

Berdasarkan hasil analisis data dan pembahasan, maka disimpulkan bahwa tidak terdapat pengaruh penerapan model Contextual Teaching and Learning Berbantuan Discord terhadap hasil belajar kognitif siswa pada sub materi Alat Indra.

\section{REKOMENDASI}

1. Penerapan model Contextual Teaching and Learning Berbantuan Discord sebaiknya dipilih materi yang dapat dikaitkan dengan dunia nyata siswa dan siswa mengalami sendiri dan mengkonstruksi pengetahuan yang dimilikinya dengan kehidupan sehari-hari.

2. Sebaiknya aplikasi E-learning yang digunakan dalam pembelajaran bisa dengan mudah diakses dan terjangkau oleh siswa.

3. Menggunakan strategi pembelajaran yang bervariasi dan tidak monoton membuat guru dapat memiliki pengalaman baru dalam penerapan suatu strategi. Sehingga kedepannya guru dapat mengenali dan mengidentifikasi kendala-kendala penerapan suatu strategi pembelajaran agar dapat diatasi dan dicari solusi permasalahannya untuk penerapan berikutnya.

4. Dalam penerapan model Contextual Teaching and Learning Berbantuan Discord guru harus lebih memiliki kemampuan mengatur waktu yang baik supaya lebih efektif dan agar siswa dapat memanfaatkan waktunya dengan baik dan benar. 


\section{DAFTAR PUSTAKA}

Hasnidar, H., \& Elihami, E. (2019). Pengaruh Pembelajaran Contextual Teaching and Learning Terhadap Hasil Belajar PKn Murid Sekolah Dasar. Jurnal Pendidikan Guru Sekolah Dasar.

Jatmiko, A. (2017). Pengaruh Model Pembelajaran dan Konsep Diri Terhadap Hasil Belajar IPA. BIOSFER Jurnal Tadris Pendidikan Biologi. 8(2) : 84-101.

Latief, H. (2014). Pengaruh Pembelajaran Kontekstual Terhadap Hasil Belajar (Studi Eksperimen pada mata pelajaran Geografi Kelas VII Di SMPN 4 Padalarang). Jurnal Pendidikan Geografi. 14(2) : 14-28

Lestari, E. K. \& Yudhanegara, R. M. (2015). Penelitian Pendidikan Matematika. Bandung : PT Refika Aditama.

Mulyono, N. (2018). Kurikulum \& Pembelajaran. Bandung : Rizqi Press.

Rakhmawan, A., Juansah, D. E., Nulhakim, L., Biru, L. T., Rohimah, R. B., Suryani, D. I., Vitasari, M., \& Resti, V. D. A. (2020). Analisis Pemanfaatan Aplikasi Discord Dalam Pembelajaran Daring di Era Pandemi COVID-19. 3(1) : 55-59.

Sudjana. (2005). Metoda Statistika. Bandung : Tarsito.

Sugiyono. (2019). Metode Penelitian Pendidikan Pendekatan Kualitatif dan R\&D. Bandung : Alfabeta.

Trianto. (2011). Mendesain Model Pembelajaran Inovatif-Progresif. Jakarta : Prenada Media Group 
